\title{
Design specifications of a heat applicator weed controller device for family farms
}

\author{
Roger Toscan Spagnolo ${ }^{1^{*}}$ André Oldoni $^{2}$ Tiago Vega Custódio ${ }^{3}$ \\ Ângelo Vieira dos Reis ${ }^{4}$ Antônio Lilles Tavares Machado ${ }^{4}$ \\ ${ }^{1}$ Núcleo de Ciências Agrárias, Instituto Federal do Rio Grande do Sul (IFRS), Campus Sertão, 99170-000, Sertão, RS, Brasil. \\ E-mail: roger.toscan@gmail.com. "Corresponding author. \\ ${ }^{2}$ Curso Técnico em Eletromecânica, Instituto Federal Sul Rio Grandense (IFSul), Campus Pelotas, Pelotas, RS, Brasil. \\ ${ }^{3}$ Programa de Pós-graduação em Sistemas de Produção Agrícola Familiar (PPGSPAF), Universidade Federal de Pelotas (UFPEL), Pelotas, RS, Brasil. \\ ${ }^{4}$ Departamento de Engenharia Rural (DER), Universidade Federal de Pelotas (UFPEL), Pelotas, RS, Brasil.
}

ABSTRACT: One of the difficulties faced by organic food farming families is weed management without the application of chemical products. Thus, this study aimed to establish the design specifications for the development of a heat applicator device for small organic family farms. The implemented methodology allowed the division of the project to phases composed by different tasks. This paper addresses the informational phase, which identifies client needs, according to the lifecycle of the product, in order to establish the design specifications. The declared needs of 40 customers were identified and converted to the requirements of 24 clients. This resulted in 26 design specifications, displayed in order of importance, and distributed along the product's entire life cycle. Nine requirements were considered to be the most important; namely working speed, target applied temperature, application height variables, weed elimination, production costs, operation costs, energy consumption, weight, and main crop damage.

Key words: informational design, product development, organic farming.

Especificações para o projeto de um mecanismo aplicador de calor para o combate de plantas espontâneas dirigido à agricultura familiar

RESUMO: Uma das dificuldades dos agricultores familiares que produzem alimentos orgânicos é o manejo de plantas espontâneas sem a aplicação de produtos químicos. Sendo assim, objetivou-se estabelecer as especificações de projeto no desenvolvimento de um mecanismo aplicador de calor para o combate de plantas espontâneas, dirigido à agricultura familiar orgânica. A metodologia de projeto utilizada permite dividi-lo em fases, que são compostas por diferentes tarefas. O presente trabalho contempla a fase de projeto informacional, na qual são identificadas as necessidades dos clientes de acordo com o ciclo de vida do produto no sentido de estabelecer as especificações de projeto. Foram identificadas 40 declarações de necessidades de clientes, as quais foram transformadas em 24 requisitos de clientes, originando 26 requisitos de projeto hierarquizados, distribuidos ao longo de todo o ciclo de vida do produto, resultando nas especificações de projeto do produto. Os nove requisitos apontados como mais importantes foram: velocidade de trabalho; temperatura aplicada ao alvo; variação da altura de aplicação; eliminação das plantas espontâneas; custo de produção; custo de operação; consumo de energia; danificação da cultura implantada e peso.

Palavras-chave: projeto informacional, desenvolvimento de produto, cultivo orgânico.

\section{INTRODUCTION}

Among the biggest challenges for organic farmers, is the control of spontaneous plants without use of chemicals. This difficulty makes it practically indispensable to mobilize the soil in order to control spontaneous plants. An alternative is a mechanism to control spontaneous plants through thermal control.

The mechanism has gas containers located next to the chassis. With the aid of a tool chassis, it is possible to vary the spacing between the lines. The presence of wheel next to the heat exchanger mechanism mantains the height of the application, even with terrain surface variation. This allows plants thermal control.

The systematic approach methodology, used in product design, is becoming very common in well-established companies, which aspire higher product quality, for the purpose of increasing their competitive edge and consequently, their sales volume (ROMANO et al., 2005).

Many design methodologies have been applied towards increasing product quality, while reducing 
cost and development time. According to REIS \& FORCELLINI (2006a), it is possible to divide the design of farm devices into four phases; namely, informational design, conceptual design, pre-initial design, and detailed design. The product models generated on each of these phases are: design specifications, product conception, final layout, and documentation.

With regard to the design of a weed controller device with heat, some factors must be highlighted. According to KANG (2001) the combination of short height and an angle between $30^{\circ}$ and $45^{\circ}$, of the heat applicator relative to the target, have an increasing effect on temperature, and thereby improve burning efficiency. In the development stage, the water amount in the weeds, used gas pressure, and heat applicator movement speed are factors that influence the amount of gas consumed by the application, control effectiveness, and culture productivity (ULLOA et al., 2010; ULLOA et al., 2012).

According to KANG (2001) the higher the liquefied petroleum gas (LPG), also known as cooking gas, the better the efficiency of spontaneous plant control. The author states that doses of less than $20 \mathrm{~kg} \cdot \mathrm{ha}^{-1}$ were not efficient, while those greater than $40 \mathrm{~kg} \cdot \mathrm{ha}^{-1}$ were able to control more than $80 \%$ of weeds.

According to ULLOA et al. (2010), largeleaf plants are more likely to be susceptible to thermal treatment, compared to strait plants. Doses of LPG within $30-60 \mathrm{~kg}^{-} \mathrm{ha}^{-1}$ were able to control $90 \%$ of the large-leaf weeds, in the stage of development between 3 and 14 leaves, while the same dose of LPG was able to control $80 \%$ of them, in strait plants, in the stage between 4 and 7 leaves. ULLOA et al. (2012) claimed that a higher thermal treatment application efficiency was reached when it was used in the period in which the leaves were less humid, which happens in the eventide high, after long exposure to sunlight.

The impact on the main crop and soil is another point that must be highlighted. According to KNEZEVIC et al. (2013), the productivity of soybean, for example, is harmed according to the number of interventions and phonological phases where the treatment is done. They recommend only two interventions per season without any yield reduction: the first one should occur when the cotyledons are completely open and expanded (VC), and the second when the fourth trifoliate leave is completely developed (V5).

SNIAUKA \& POCIUS (2008) claimed that the instantaneous impact of the applied flames on the ground is minimal. According to the authors, flames with an intensity of $4.600 \mathrm{MJ}^{-h^{-1}} \mathrm{had}^{\mathrm{a}}$ a reducing effect on soil microfiber as was observed when the soil profile was analyzed for up to $5 \mathrm{~mm}$ of depth. At this depth, the soil temperature increased by $3^{\circ} \mathrm{C}$. At $10 \mathrm{~mm}$, it increased by $1^{\circ} \mathrm{C}$, and at $20 \mathrm{~mm}$ there was no increase observed in soil temperature.

Thermal treatment is a worthwhile option for controlling weeds in organic and conventional production systems. The propane gas used to control them, can be adopted as an alternative to chemical control, once complaints about residual effects on the soil, water and food quality have been addressed. Moreover, it can reduce the use of herbicides, manual cleaning and/or mechanical cultivation (DATTA \& KNEZEVIC, 2013).

In this context, this study aimed to establish design specifications, which can be used to develop a weed control applicator device for family farms.

\section{MATERIALS AND METHODS}

Many authors (BACK et al., 2010; REIS \& FORCELLINI, 2006b; STEFANELLO et al., 2016) use and indicate similar methodologies to define design specifications, when these are set as quantitative targets, and the method to evaluate them. Sequence of steps, tasks, and tools used, are not identical, since each design has its own characteristic problems. The flowchart shown in figure 1, was created with the aim of conceptualizing a new device, which will address the stated problem. A description for each step of the activities depicted in the flowchart is provided below.

\section{Step 1.1: Search for information on the design topic}

In this phase, technical information was obtained through researching the literature (books, articles, patents) and other similar systems, as well as through product analysis.

\section{Step 1.2: Identify client needs}

The identification of client needs was carried out through researching the literature, similar product analysis, and external client interviews (agro-eco farmers). For the development of the questionnaire used to support the interviews, the methodology proposed by MARCONI \& LAKATOS (2010) was used, with the purpose of collecting information about problems related to plant control, and the socioeconomic needs interfering with the project's development.

Interviews, via a questionnaire was the main tool used during this phase. Interviewing was performed with 23 family farmers, who were organic food producers. The interviews were performed in meetings and fairs organized by the Sul-Ecológica Cooperative in Pelotas, RS. 


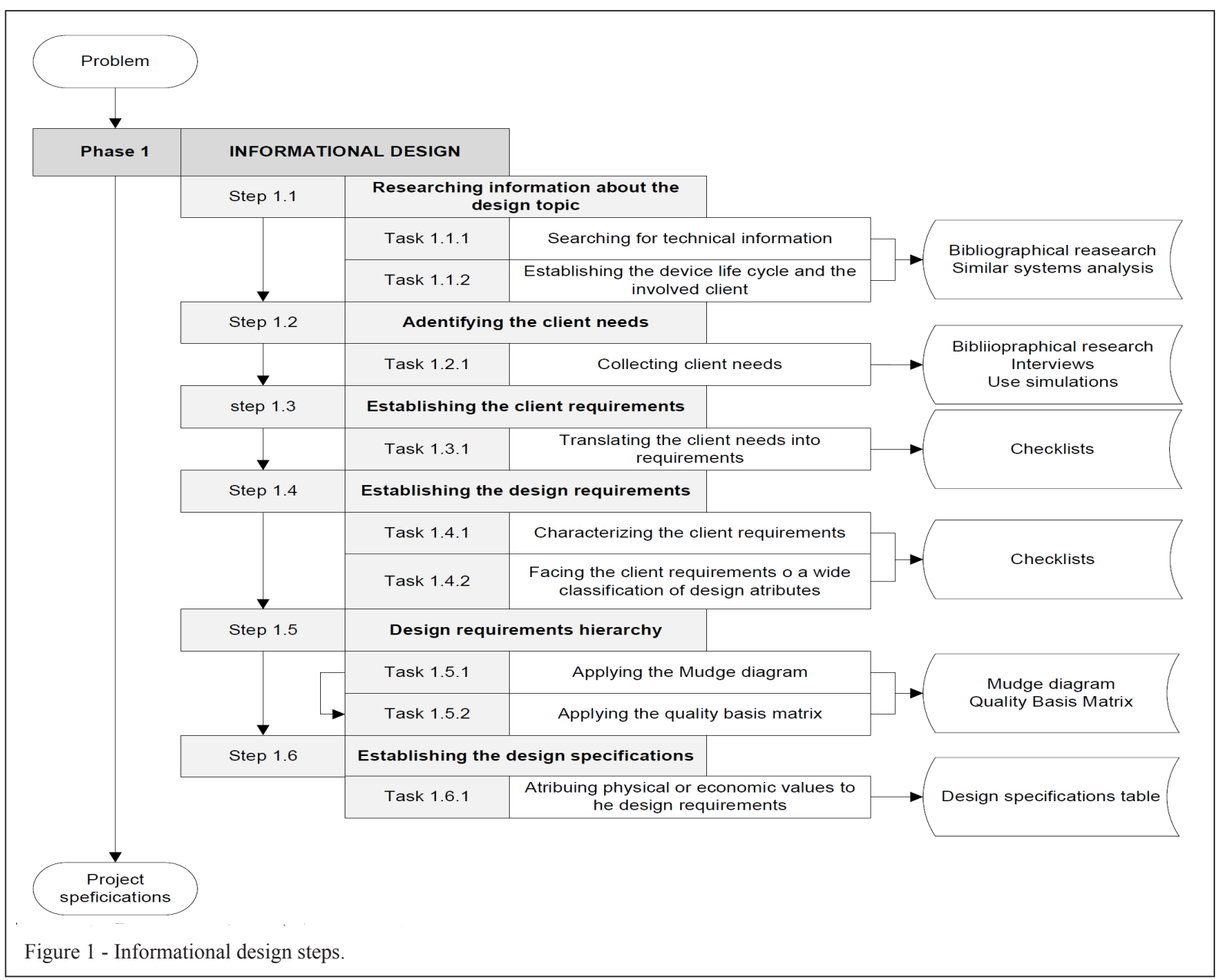

Usage simulations, with heat applicator beaks, were performed; a test stand was made in order to quantify the flames generated from the maximum temperatures of the four burners, at different pressures $(49,0,65,5$, and $126,9 \mathrm{kPa})$ and application height $(10$, $20,30$, and $40 \mathrm{~cm})$.

\section{Step 1.3: Establish client requirements}

After identifying client needs, the process of transforming these needs into requirements commenced. This was achieved by translating the client's colloquial language, which was used to describe their needs, into Engineering language, which was more compact and appropriate for the general understanding of the device development team.

This conversion was performed by implementing the approach used by REIS \& FORCELLINI (2006a) in a precise doser project. Accordingly, each requirement was described by a shorter phrase composed by the verbs "have" and "be" followed by a noun or more. If the sentence was composed by a different verb, the requirement would be probably implemented as a device function.

\section{Step 1.4: Establish design requirements}

In this step, customer requirements are associated with the measured characteristics of the product, and the design requirements emerge there from. According to REIS \& FORCELLINI (2006a), at first, a list of attributes, for the requirements of each client, must be established in order to make each requirement comprehensible, and characterization less difficult.

In a second study, REIS \& FORCELLINI (2006b) proposed that client requirements should be subjected to a wider classification of device attributes. After that was done for each classification item, it was possible to obtain a wide list of device requirements, which were analyzed with regard 
to completeness, operability, non-redundancy, concision, and practicability. A list conceived in this way, must contain requirements from all the clients involved in the entire life cycle of the product.

\section{Step 1.5: Prioritize design requirements}

The quality function deployment (QFD) method is a tool which relates client and design requirements by their importance. Accordingly, it was used to generate a list of design requirements in order of importance.

The first task,in which the QFD was used was the evaluation of client requirements ("what does the customer need?"). This was performed through the Mudge diagram application, which is a relationship matrix aiming to weigh the importance of one customer requirement in relation to others, and thereby render them measurable. The second task was the QFD. This matrix was filled with the help of a computer program called QFD-SACPRO developed by the Nucleous of Integrated Products Development, of the Universidade Federal de Santa Catarina (NEDIP-UFSC).

\section{Step 1.6: Establish design specifications}

In this task, a design specification structure is generated. It consisted of assigning a goal value, physical and/or economic magnitude, evaluation form, and undesirable aspects, if the target value is reached.

\section{RESULTS AND DISCUSSION}

Through the methodology illustrated in figure 1, the results related to client needs and requirements, design requirements, and its own specifications, were generated.

\section{Client needs and requirements}

The interview analysis, bibliographic review, and the experiments performed with the heat applicator devices, have allowed the acquirement of the declared needs of 40 clients. These needs were distributed along the device's entire life cycle, as can be observed in table 1, which also presents customer requirements generated from the illustrated needs.

\section{Design requirements}

The characterization of client requirements was the first procedure performed during this phase .Each requirement was characterized in order to improve comprehensibility, since in table 1 client requirements are not completely contextualized. Subsequently, these requirements were subjected to wider device attribute classification used by REIS\&FOCELLINI (2006b).
Figure 2 shows the QFD by which it is possible to observe the 26 design requirements in the columns (How).

Figure 2 shows the relationship between client requirements and design requirements, correlation between the design requirements, hierarchy of the design requirements, and classification without considering a correlation between the design requirements. Through the QFD (Figure 2) it was possible to verify that work speed was the most important requirement while the second most important was the temperature applied to the target followed by the variation of the application height. This information showed that the efficiency of the mechanism is an important feature, as these requirements are essential to the purpose of the equipment.

\section{Design requirements hierarchy}

The classification of client requirements, using the Mudge diagram provided knowledge on the order of importance. The eight more important requirements were to be effective in weed elimination $(10,47 \%)$, be inoffensive to the main crop $(10,47 \%)$, have uniform heat application height $(7,29 \%)$, be inoffensive to soil $(7,29 \%)$, low energy cost $(6,94 \%)$, be safe $(6,35 \%)$, have system controls $(5,65 \%)$, and be easy to operate $(5,65 \%)$.

Figure 2 shows the QFD, where the relationship among client and design requirements, and the correlation among design requirements and their hierarchy, can be seen.

\section{Establishing design specifications}

Design specifications are presented according to their degree of importance, which was obtained in the QFD shown in table 2. The division of the design requirement hierarchy, into three parts was necessary in the subsequent phases of the project. Decision making was conducted according to this hierarchy, while the team priority was to reach the established goals of the classified demands in the superior third (Table 2).

The use of the present methodology provided the design team with knowledge on the worked subject. By the end of each informational design step, it was observed that team members had acquired a progressive understanding with regard to the complexity of the problem under investigation.

The step of identifying client needs must be highlighted because of its importance and contribution of scientific knowledge to the design team. The interviews of organic farmers (external clients) brought up aspects related to property size, main crop, traction source used, and income of these farming families. From this information the client 
Table 1 - Client needs and requirements separated by phases of the device's life cycle.

\begin{tabular}{|c|c|c|}
\hline $\begin{array}{l}\text { Phase of the device } \\
\text { life cycle }\end{array}$ & Client needs & Client requirements \\
\hline \multirow[t]{2}{*}{ Project } & 1. Project that a smith can execute & Having a simple design $(1,2)$ \\
\hline & 2. Avoid complex shapes & \\
\hline \multirow[t]{4}{*}{ Production } & 3. Cheap production & Having simple production processes $(3,4,5)$ \\
\hline & 4. Easy to produce & \\
\hline & 5. Minimal time of production & \\
\hline & 6. Use standard products at maximum & Having standard pieces (6) \\
\hline \multirow[t]{4}{*}{ Sells } & 7. Pleasant colors & Having finishing $(7,8,9)$ \\
\hline & 8. Pleasant shapes & \\
\hline & 9. Avoid alive corners & \\
\hline & 10. Less sell price possible & Having low cost (10) \\
\hline \multirow{25}{*}{ Operation } & 11. Easy to regulate & Having simple regulation (11) \\
\hline & 12. More than one harvest use & Having variable space of application $(12,13)$ \\
\hline & 13. No harvest use & \\
\hline & 14. Easy to operate & Easy to handle $(14,15)$ \\
\hline & 15. Small areas use & \\
\hline & 16. Low weight & Having low weigth (16) \\
\hline & 17. Useful in low potency tractors & Having engine low potency $(17,18)$ \\
\hline & 18. Engine low potency need & \\
\hline & 19. Heat application in different height plants & Having a uniform application height $(19,20)$ \\
\hline & 20. Keep the heat applicator height & \\
\hline & 21. Eliminate weeds with the lower number of interventions & Being effective on the plants elimination (21) \\
\hline & 22. Present thermal isolation & Being safe $(22,23,24)$ \\
\hline & 23. Protect the mobile parts & \\
\hline & 24. Safety warnings in eminent accident places & \\
\hline & 25. Low operation cost & Having low energy consumption (25) \\
\hline & 26. Not to harm the crop & Being inoffensive to the crop (26) \\
\hline & 27. Offer reduced efforts on the device installing and removal & Being ergonomic $(27,28)$ \\
\hline & 28. Operation comfort and practicability & \\
\hline & 29. Easy to transport & Being easy to transport (29) \\
\hline & 30. Operator visibility of the system critical points & Having systems visibility (30) \\
\hline & 31. System intervention possibility during the operation & Having systems control (31) \\
\hline & 32. Easy and instructive interaction between man and device & Being easy to operate (32) \\
\hline & 33. Not to reduce the alive organisms present in the soil & Being inoffensive to the soil (33) \\
\hline & 34. Avoid flames appearance during the use & Being useful on the straw presence $(34,35)$ \\
\hline & 35. Useful in direct plantation systems & \\
\hline \multirow[t]{5}{*}{ Maintenance } & 36. Low maintenance cost & Being of simple maintenance $(36,37,38,39)$ \\
\hline & 37. Minimal time for maintenance & \\
\hline & 38. Reduced maintenance frequency & \\
\hline & 39. Low tool use during maintenance & \\
\hline & 40. Long useful life & Being durable (40) \\
\hline
\end{tabular}

demands/requirements were determined based on the needs of low income families. The requirements of turning radius, horizontal free space, engine strength, and weight were based on property characteristics such as reduced size of the good, different crops produced, and available traction source, which comes from a four-wheel tractor with a potency less than 55 $\mathrm{kW}$, in the majority of cases. 


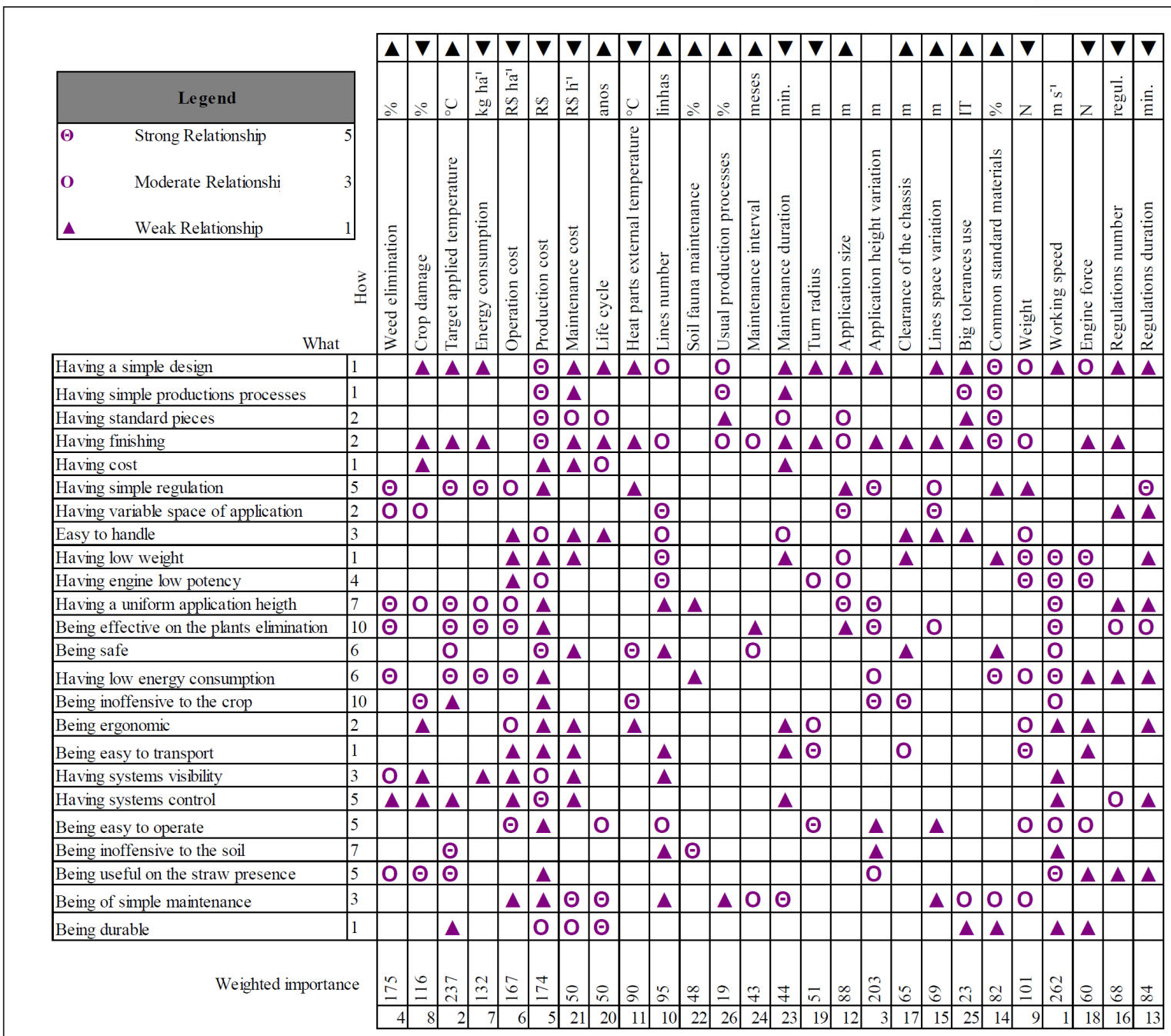

Figure 2 - Quality function deployment.

Another informational step; which is harder and longer, but essential, must be emphasized; namely design requirements hierarchy, consisting of the QFD matrix filling. The research starts with the evaluation of client requirements through the Mudge diagram application, which illustrates 300 relationships. Subsequently, the requirements of 24 clients were related to the 26 design requirements in the QFD (Figure 2), and amounted to 674 possible relationships. Therefore, it is clear that team effort during the informational design phase focused on the use of the first QFD matrix, which is a tool that allowed the establishment of the design requirements importance degree.

The design requirements in table 2 (working speed, temperature applied to the target, application height variation, weed elimination, energy consumption, and harvest damage), which were most valued by the project team, are related to the functional performance of the device. This reveals a user concern regarding product effectiveness, which does not have a precedent in the market. In addition, these results corroborated with concerns cited by ULLOA et al. (2010, 2012). Even though the goals related to operation were established based on similar devices reported by market patent analysis and stand tests, it is clear that, in subsequent phases, the device will need prototype conception, as well as field tests, in order to analyze its technical and economic viability.

The economic aspects related to production costs, maintenance, operation, and gas usage, must be carefully observed during the project, since the 
Table 2 - Design specifications obtained through QFD in order of importance.

\begin{tabular}{|c|c|c|c|}
\hline Requirement & Goal Value & Evaluation Form & Undesired Aspects \\
\hline \multicolumn{4}{|c|}{ Superior Third } \\
\hline 1. Working speed & $\leq 1,39 \mathrm{~m} \cdot \mathrm{s}^{-1}$ & Field test & Operational capacity reduction \\
\hline $\begin{array}{l}\text { 2. Applied temperature } \\
\text { to the target }\end{array}$ & $\geq 100^{\circ} \mathrm{C}$ & Simulation in a test stand & $\begin{array}{l}\text { High soil, straw and device surface } \\
\text { heating }\end{array}$ \\
\hline $\begin{array}{l}\text { 3. Application variation } \\
\text { height }\end{array}$ & Between 0,05 and $0,4 \mathrm{~m}$ & Simulation in a test stand & $\begin{array}{l}\text { Energy dissipation, device break on } \\
\text { rocks presence, gravity center alteration }\end{array}$ \\
\hline 4. Weeds elimination & $\begin{array}{l}\text { Elimination } \\
\geq 80 \% / \text { passed }\end{array}$ & Flied tests & Make more than one intervention \\
\hline 5. Production cost & $\leq \mathrm{R} \$ 1.500,00$ & $\begin{array}{l}\text { Amount of costs values with } \\
\text { materials, processes and workers }\end{array}$ & $\begin{array}{l}\text { Quality and performance compromised, } \\
\text { elements reduction }\end{array}$ \\
\hline 6. Operation cost & $\leq \mathrm{R} \$ 200,00 \cdot \mathrm{ha}^{-1}$ & Field test & $\begin{array}{l}\text { Traction resource type and ineffective } \\
\text { weed elimination restriction }\end{array}$ \\
\hline 7. Energy consumption & $\leq 40 \mathrm{~kg} \cdot \mathrm{GLP} \cdot \mathrm{ha}^{-1}$ & Laboratory tests & Ineffective weed elimination \\
\hline 8. Harvest damage & Death $\leq 5 \%$ & Field tests & $\begin{array}{l}\text { Weed elimination effectiveness } \\
\text { reduction }\end{array}$ \\
\hline 9. Weight & $<4.000 \mathrm{~N}$ & Laboratory quantification & $\begin{array}{l}\text { Lighter materials use, production cost } \\
\text { increase }\end{array}$ \\
\hline \multicolumn{4}{|c|}{ Medium Third } \\
\hline 10. Lines number & $\geq 2$ lines & $\begin{array}{c}\text { Traction capacity and project layout } \\
\text { analysis }\end{array}$ & $\begin{array}{l}\text { Increase in weight and dimensions, } \\
\text { maneuver difficulty, traction force need } \\
\text { increase }\end{array}$ \\
\hline $\begin{array}{l}\text { 11. Heat external parts } \\
\text { temperatures }\end{array}$ & $\leq 50^{\circ} \mathrm{C}$ & $\begin{array}{c}\text { Calculation based on insulating } \\
\text { materials characteristics, evaluation } \\
\text { on the field }\end{array}$ & $\begin{array}{l}\text { Weight increase and more expensive } \\
\text { materials use }\end{array}$ \\
\hline 12Applicator size & $\geq 0,4 \mathrm{~m}$ & Test stand and field simulation & $\begin{array}{c}\text { Main crop with spaces lower than } 0,4 \mathrm{~m} \\
\text { use restriction }\end{array}$ \\
\hline 13. Regulation duration & $\leq 20 \mathrm{~min}$ & Laboratory timing & $\begin{array}{l}\text { Regulation quality, production cost } \\
\text { increase }\end{array}$ \\
\hline $\begin{array}{l}\text { 14. Common standard } \\
\text { materials }\end{array}$ & $\geq 80 \%$ & Laboratory counting & $\begin{array}{l}\text { Compromising performance and } \\
\text { functioning }\end{array}$ \\
\hline $\begin{array}{l}15 . \text { Space among lines } \\
\text { variation }\end{array}$ & 0 a $0,9 \mathrm{~m}$ & Laboratory tests & $\begin{array}{l}\text { Higher components number, production } \\
\text { cost increase }\end{array}$ \\
\hline 16. Regulations number & $\leq 5$ & Laboratory counting & $\begin{array}{l}\text { Production cost increase, functioning } \\
\text { compromised }\end{array}$ \\
\hline $\begin{array}{l}\text { 17. Clearance of the } \\
\text { chassis }\end{array}$ & $\geq 0,4 \mathrm{~m}$ & Laboratory test & Vertical gravity center increase \\
\hline 18. Engine force & $<1.500 \mathrm{~N}$ & Field test & Vertical gravity center increase \\
\hline \multicolumn{4}{|c|}{ Inferior Third } \\
\hline 19.Turning radius & $\leq 4 \mathrm{~m}$ & Field test & Potency resource restriction \\
\hline 20. Life cycle & $\geq 10$ years & $\begin{array}{l}\text { Technical and practices adoption } \\
\text { during the project to guarantee the } \\
\text { goal }\end{array}$ & $\begin{array}{l}\text { Expensive and difficult to acquire } \\
\text { materials used. }\end{array}$ \\
\hline 21. Maintenance cost & $\leq \mathrm{R} \$ 32,00 \mathrm{~h}^{-1}$ & $\begin{array}{l}\text { Values expend with materials, } \\
\text { processes and workers amount }\end{array}$ & $\begin{array}{l}\text { Corrective maintenance necessity, } \\
\text { operation cost increase and life cycle } \\
\text { reduction }\end{array}$ \\
\hline $\begin{array}{l}\text { 22. Soil fauna } \\
\text { maintenance }\end{array}$ & $95 \%$ & Soil meso and macro fauna analysis & Weed elimination ineffectiveness \\
\hline $\begin{array}{l}\text { 23. Maintenance } \\
\text { duration }\end{array}$ & $\leq 2$ hours & Timing with stand test simulation & $\begin{array}{l}\text { Service quality compromised, } \\
\text { maintenance spaces reduction }\end{array}$ \\
\hline $\begin{array}{l}\text { 24. Space between the } \\
\text { maintenances }\end{array}$ & 12 months & $\begin{array}{l}\text { Technical and practices adoption } \\
\text { during the project to guarantee the } \\
\text { goal }\end{array}$ & $\begin{array}{l}\text { Corrective maintenances appearance } \\
\text { production cost increase through higher } \\
\text { quality materials use }\end{array}$ \\
\hline 25. High tolerance use & IT9 e IT11 classes & Prototype pieces dimension control & $\begin{array}{l}\text { Tolerance use that can cause wear and } \\
\text { backlashes }\end{array}$ \\
\hline $\begin{array}{l}\text { 26. Usual production } \\
\text { procedure }\end{array}$ & $>80 \%$ & Laboratory counting & $\begin{array}{c}\text { Innovative solutions that need different } \\
\text { processes concretion limitation }\end{array}$ \\
\hline
\end{tabular}

Ciência Rural, v.48, n.2, 2018. 
monthly income of these families is considered low and does not exceed $\mathrm{R} \$ 5.000$, in most cases. According to TEIXEIRA et al. (2009), low income, low devices, and implements adapted to the organic farmers' specific needs, are the main barriers to new technology acquisition.

When a device uses a heat source to control weeds, security is also an important aspect of the design specifications (Requirement 11). Accordingly, the heat should not damage the main crop and, at the same time, it should avoid accidents to the operator. During the informational design stage, it was considered that the heated parts must be protected with insulating materials.

The design specification analysis allowed us to deduce that the device weed controller with heat, must be applied with precision and adapted to different cultures. Its design must focus on security and the reduction of production and operational costs, while avoiding injuries to the farmer during operation and maintenance.

\section{CONCLUSION}

Working speed is one of the main considerations in the design of a heat applicator device for family farms, as its variation can damage crops or render control ineffective. The target temperature for plant control should be above the vaporization temperature of the water.

The equipment must have temperature control as a target, in order to provide low LPG consumption. The heat applicator equipment must have variable application height and LPG expansion, as well as low mass, low production cost, and low operation cost.

\section{REFERENCES}

BACK, N. et al. Projeto integrado de produtos: planejamento, concepção e modelagem. Barueri, SP: Manole, 2010. 648p.

DATTA, A.; KNEZEVIC, S. Z. Flaming as an alternative weed control method for conventional and organic agronomic cropp production systems: a review. Advances in Agronomy. v.118, p. 399-428, 2013. Available from: <https://doi.org/10.1016/B978-0-12-405942-9.000062>. Accessed: mar. 30, 2016. doi: 10.1016/B978-0-12-405942-9.00006-2.

KANG, W. S. Development of a flame weeder. American Society of Agricultural Engineers. v.44, p.1065-1070, 2001. Available from: $<$ http://dx.doi.org/10.13031/2013.6428>. Accessed: mar. 30, 2016. doi: $10.13031 / 2013.6428$.
KNEZEVIC, S. Z. et al. Soybean yield and yield components as influenced by the single and repeated flaming. Crop Protection. v.50, p.1-5, 2013. Available from: <http://dx.doi.org/10.1016/j. cropro.2013.03.014>. Accessed: Dez. 12, 2016. doi: 10.1016/j. cropro.2013.03.014.

MARCONI, M. A.; LAKATOS, E. M. Fundamentos de metodologia científica.7 ed. São Paulo, SP: Atlas, 2010. 320p.

QFD-SACPRO. Software desenvolvido pelo Núcleo de Desenvolvimento Integrado de Produtos da Universidade Federal de Santa Catarina (NEDIP-UFSC). Available from: $<$ http://www.nedip. ufsc.br/site/index.php?link=softwares $>$. Accessed: Jun. 22, 2015.

REIS, A. V.; FORCELLINI, F. A. Identificação de requisitos de clientes para o projeto de um dosador de precisão para sementes miúdas. Engenharia Agrícola, v.26, n.1, p.309-20, 2006a. Available from: $<\mathrm{http}: / /$ www.scielo.br/scielo.php?script=sci_arttext\&pid=S010069162006000100033\&lng=pt\&nrm=iso>. Accessed: Mar. 12, 2017. doi: $10.1590 / \mathrm{S} 0100-69162006000100033$.

REIS, A. V.; FORCELLINI, F. A. Obtenção de especificações para o projeto de um mecanismo dosador de precisão para sementes miúdas. Engenharia Rural, v.17, n.1, p.47-57, 2006b. Available from: $\quad<$ http://wp.ufpel.edu.br/nimeq/files/2011/04/EngenhariaRural-v17-n1.pdf>. Accessed: Oct. 15, 2016.

ROMANO, L. N. et al. An Introduction to The Reference Model for the Agricultural Machinery Development Process. Product: Management \& Development, v.3, n.2, p.109-132, 2005. Available from: <http://citeseerx.ist.psu.edu/viewdoc/do wnload?doi=10.1.1.471.853\&rep=rep1\&type=pdf. $>$. Accessed: Nov. 20, 2016.

SNIAUKA, P.; POCIUS, A. Thermal weed control in strawberry. Agronomy Research, v.6, p.359-366, 2008. Available from: <http:// agronomy.emu.ee/vol06Spec/p6S21.pdf >. Accessed: Mar. 28, 2017.

STEFANELlO, G. et al. Design specifications of a humanpowered planter. Ciência Rural, v.46, n.12, p.2118-2121, dez, 2016. Available from: $<$ http://www.scielo.br/scielo.php?script=sci arttext\&pid=S0103-84782016001202118>. Accessed: Mar. 30, 2017. doi: $10.1590 / 0103-8478 \mathrm{cr} 20160262$.

TEIXEIRA, S. S. et al. Caracterização da produção agroecológica do sul do Rio Grande do Sul e sua relação com a mecanização agrícola. Engenharia Agrícola, v.29, n.1, p.165-171, 2009. Available from: <http://www.scielo.br/scielo.php?pid=S010069162009000100016\&script $=$ sci abstract\&tlng $=p t>$. Accessed: Mar. 29, 2017. doi: 10.1590/S0100-69162009000100016.

ULLOA, S. M. et al. Tolerance of selected weed species to broadcast flaming at different growth stages. Crop Protection, v.29, p.1381-1388, 2010. Available from: <https://doi.org/10.1016/j.cropro.2010.07.017>. Accessed: Nov. 10, 2016. doi: 10.1016/j.cropro.2010.07.017.

ULLOA, S. M.; et al. Weed control and crop tolerance to propane flaming as influenced by the time of day. Crop Protection, v.31, p.1-7, 2012. Available from: <https://doi.org/10.1016/j. cropro.2011.09.005>. Accessed: Nov. 10, 2016. doi: 10.1016/j. cropro.2011.09.005. 